ROCZNIKI PEDAGOGICZNE

Tom 12(48), numer $3-2020$

DOI: https://doi.org/10.18290/rped20123-8

DOROTA KORNAS-BIELA

\title{
OJCOSTWO MĘŻCZYZN \\ WYCHOWUJĄCYCH DZIECI Z USZKODZONYM SŁUCHEM \\ CZĘŚĆ I
}

Rodzina pełna jest dla dziecka ogromną wartością. Znaczenia obecności, roli i zaangażowania ojca $\mathrm{w}$ rodzinie i w życiu dziecka nie da się przecenić. Dotyczy to każdej rodziny i każdego dziecka, jednak w sytuacji niepełnosprawności znaczenie zaangażowania ojcowskiego jest szczególnie istotne. Niestety, w badaniach nad funkcjonowaniem rodzin $\mathrm{z}$ dzieckiem $\mathrm{z}$ niepełnosprawnością ojciec jest zwykle „wielkim nieobecnym”, chociaż w ostatnich latach coraz częściej pojawiają się studia uwzględniające jego rolę w rozwoju, wychowaniu i rehabilitacji dziecka ze specjalnymi potrzebami edukacyjnymi. Ów brak ojca w badaniach empirycznych wynika nie tylko z faktu, że najczęściej to matka jest osobą najbardziej zaangażowaną w towarzyszenie dziecku z niepełnosprawnością w jego rozwoju ${ }^{2}$, jest zainteresowana wszystkim, co dotyczy dziecka, i w związku z tym bardziej chętna do wzięcia udziału w badaniach, ale również z tego, że ojcowie są trudno dostępni do badań ze względu na zaangażowanie zawodowe (np. długi czas pracy, praca $\mathrm{z}$ dala od domu), jak też niechętni do udzielania informacji o sobie.

Jedną z grup osób z niepełnosprawnością są osoby z uszkodzeniem słuchu ${ }^{3}$. Jak wynika z raportu Instytutu Fizjologii i Patologii Słuchu w Kajetanach

Dr hab. Dorota Kornas-Biela, prof. KUL - Katedra Pedagogiki Specjalnej, Instytut Pedagogiki, Wydział Nauk Społecznych, Katolicki Uniwersytet Lubelski Jana Pawła II; adres do korespondencji: Al. Racławickie 14, 20-950 Lublin; e-mail: dorota@biela.pl; ORCID: https://orcid. org/0000-0001-6002-1901.

${ }^{2}$ Niewiele się w tym zakresie zmieniło na przestrzeni kilkudziesięciu lat, gdy M. Góralówna i A. Domańska (1966) wydając książkę Dziecko niesłyszące w rodzinie, zaadresowały ją do matek (por. Gałkowski, 1973, s. 84-90; Góralówna, Hołyńska, 1984, s. 11-19; Eckert, 1986, s. 16-21).

${ }^{3} \mathrm{~W}$ stosunku do tej grupy osób używa się różnych określeń - $\mathrm{z}$ wadą słuchu, z zaburzeniem słuchu, niedosłyszący, słabosłyszący, niesłyszący, ogłuchły, głuchy, kiedyś używano terminu - 
(k. Nadarzyna) relacjonującego rezultat 20-letnich badań przesiewowych noworodków oraz dzieci w wieku wczesnoszkolnym i szkolnym, co piąte dziecko do 18 roku życia (20\%) w Polsce może mieć różnego typu problemy ze słuchem (Korneluk i in. 2012, dostęp: 27.03.2020). K. Krakowiak jako pierwsza opracowała klasyfikację funkcjonalną osób z uszkodzonym słuchem, wzbogacając tym samym polską literaturę surdologiczną o zupełnie nowe podejście w tym zakresie. Klasyfikacja ta obejmuje następujące grupy osób: 1. funkcjonalnie słyszące $-\mathrm{z}$ nieznacznym lub lekkim obniżeniem sprawności słyszenia, 2. niedosłyszące $-\mathrm{z}$ umiarkowanym obniżeniem sprawności słyszenia, 3. słabosłyszące - ze znacznym obniżeniem sprawności słyszenia, oraz 4. niesłyszące - osoby, które nie korzystają ze słuchu w komunikacji językowej. Są one funkcjonalnie głuche ${ }^{4}$ (Krakowiak, 2013, s. 115-127). Termin „dziecko niesłyszące” będzie używany jako synonim dziecka z uszkodzeniem słuchu, a więc zarówno niedosłyszącego, słabosłyszącego, jak i niesłyszącego w nomenklaturze K. Krakowiak.

W obecnym artykule, który stanowi podstawę teoretyczną pod zamieszczony w niniejszym numerze Roczników Pedagogicznych artykuł relacjonujący wyniki badań empirycznych ojców dzieci niesłyszących (Kornas-Biela, Tupaj, 2020), skupiono się na charakterystyce polskiej oraz zagranicznej literatury psychopedagogicznej dotyczącej ojców dzieci z uszkodzeniem słuchu oraz różnic między funkcjonowaniem ich samych i matek tych dzieci. Obecny przegląd literatury ze względu na ramy artykułu nie wyczerpuje zagadnień dotyczących ojcostwa dziecka niesłyszącego podejmowanych przez badaczy na całym świecie, ale przybliża czytelnikowi zakres problemów, które są przedmiotem zainteresowania empirycznego.

\section{WYBRANE PROBLEMY OJCOSTWA DZIECI NIESŁYSZĄCYCH PODEJMOWANE W SURDOPEDAGOGICE POLSKIEJ}

O potrzebie włączenia obojga rodziców do aktywnej pracy nad dzieckiem niesłyszącym na terenie domu oraz współpracy ze specjalistami na terenie różnych poradni oraz przedszkola i szkoły pisał już wiele lat temu T. Gałkowski (1973, s. 84-90; Gałkowski, Kunicka-Kaiser, Smoleńska, 1976,

głuchoniemy. E. Domagała-Zyśk (2014) wyróżniła 7 głównych kategorii osób z uszkodzeniem słuchu: niesłyszący, niedosłyszący, słabosłyszący, późnoogłuchli, głuchoniewidomi, użytkownicy implantów, funkcjonalnie słyszący.

${ }^{4}$ Są to osoby z ubytkiem głębokim o różnym stopniu i K. Krakowiak dzieli je na 3 grupy w zależności od stopnia głębokości ubytku słuchu - grupa „brązowa”, „,srebrna” i ,złota” (2013, s. 115). 
s. 157-169). Wskazywał on na rolę czynników osobowościowych, jakie tkwią po stronie samych rodziców oraz dziecka, a które mogą ułatwiać lub utrudniać efektywność współpracy rodziców z profesjonalistami, oraz na konieczność nastawienia ich „na długie oczekiwanie pozytywnych rezultatów i przyjmowanie za sukces nawet nieznacznych oznak postępów u dziecka" (Gałkowski, 1973, s. 87).

Większość publikacji w języku polskim odnosi się do rodziców dzieci z ubytkiem słuchu, ale nie koncentruje się na ukazaniu specyficznej różnicy w zakresie przeżyć i funkcjonowania matek i ojców (np. Jędrzejczak, 1967; Klaczak, 1996; Kobosko, 1999, 2011a,b; Krakowiak, 2001; Kosmalowa, 2001, 2002; Jasiński, 2004; Marcinkowska, 2009; Borowicz, 2012b; Plutecka, 2017; Czyż, 2018). J. Kobosko zwróciła uwagę na występującą często w pracach dotyczących rodziców dzieci niesłyszących tendencję do nadmiernego uogólniania, tzn. mowa jest o rodzicach, ale tekst odnosi się do matek lub oparty jest na wynikach badań, w których ojcowie stanowili zdecydowaną mniejszość, i czasami nie są one nawet przytaczane (2013b, s. 37).

Problematyka różnic międzypłciowych w doświadczeniach rodziców po diagnozie uszkodzenia słuchu u dziecka została podjęta przez D. Kornas-Bielę (2001) przy okazji charakteryzowania stadiów adaptacji rodziców do tej sytuacji. Autorka wskazała na niektóre różnice w przeżyciach matek i ojców, w sposobach ich reakcji oraz zaznaczyła - co jest ważne w procesie udzielania im pomocy - aby uwzględniała ona różnice międzypłciowe w przeżyciach i ich ekspresji. Podobnie M. Karwowska (2009) wspomniała w swoim opracowaniu o różnicy w ujawnianiu emocji przeżywanych po uzyskaniu diagnozy o niepełnosprawności dziecka. W społecznym odbiorze jest przyzwolenie na uzewnętrznianie swoich silnych negatywnych reakcji przez matki, natomiast u ojców bywa to uznawane za objaw słabości. Dlatego ojcowie mogą przeżywać blokadę uczuć, dysonans między miłością i akceptacją dziecka z niepełnosprawnością, trudności w sprostaniu oczekiwanemu społecznie wizerunkowi „twardego mężczyzny”, a to może hamować ich zaangażowanie na rzecz dziecka, tym bardziej że matki często odsuwają mężczyznę od opieki i wychowania.

Doświadczenia ojca oraz jego rola w życiu dziecka $\mathrm{z}$ niepełnosprawnością słuchową jest w Polsce coraz częściej podejmowana (np. Ilczuk, 1999; Jasiński, 2004; Skałbania, Marszałek, 2010; Kaniok, 2011; Zakrzewska-Manterys, 2011; Korzon, 2013; Kornas-Biela, 2016; Plutecka 2013a,b; Kobosko, 2013a,b, Bulicz, 2015). K. Plutecka (2013a), opierając się na własnym materiale empirycznym, zaprezentowała szerokie spektrum roli ojca $\mathrm{w}$ rodzinie 
w obszarze wychowania, kształcenia, rehabilitacji i socjalizacji dziecka z niepełnosprawnością słuchową, jego znaczenie dla zwiększenia osiągnięć edukacyjnych dziecka oraz trudności, na jakie napotyka on w realizacji swoich funkcji rodzicielskich. Jednocześnie M. Farnicka (2011, s. 27) zwróciła uwagę, że bliski związek dziecka niesłyszącego z jednym z rodziców, a jest nim najczęściej matka, powoduje wycofanie się ojca, zarówno z relacji rodzicielskiej, jak i małżeńskiej.

Przykładu badań porównawczych nad stresem rodzicielskim dostarczyła m.in. A. Borowicz (2012b). Autorka, pracując z 58 matkami i 27 ojcami, stwierdziła, że stres całkowity dla grupy badanej sięgnął powyżej 75 centyla, czyli rodzice ci są w znaczącym stopniu zestresowani, a średni wynik w odniesieniu do stresu ojców był wyższy niż dla matek (istotnie wyższy stres związany z przywiązaniem i zdolnościami adaptacyjnymi dziecka). Średni poziom wsparcia uzyskanego od współmałżonka w grupie ojców był natomiast istotnie wyższy niż $\mathrm{w}$ grupie matek (nikt $\mathrm{z}$ ojców nie ocenił poziomu wsparcia od żony na zero), co świadczy o tym, że ojcowie wyżej niż matki oceniają wsparcie uzyskane od współmałżonka.

Doświadczenia związane z posiadaniem dziecka niesłyszącego są źródłem sytuacji trudnych, obciążających psychikę rodziców, dlatego są oni narażeni na zaburzenia zdrowia psychicznego. Badacze z Instytutu Fizjologii i Patologii Słuchu Światowego Centrum Słuchu w Nadarzynie k. Warszawy podjęli się oceny stanu zdrowia psychicznego 153 rodziców (111 matek i 42 ojców) dzieci z głuchotą prelingwalną, korzystających z jednego implantu ślimakowego, i tyleż samo rodziców dzieci słyszących (116 matek i 37 ojców). W wyniku tych badań stwierdzono m.in., że ojcowie dzieci niesłyszących przejawiają znacząco więcej objawów depresyjnych niż ojcowie dzieci o typowym rozwoju. Matki dzieci niesłyszących przejawiają istotnie więcej objawów somatycznych i lękowych niż ojcowie tych dzieci. Nie stwierdzono związku między stanem zdrowia psychicznego ojców i matek dzieci niesłyszących a ich wykształceniem oraz czasem korzystania przez dziecko z implantu ślimakowego (Kobosko, Geremek-Samsonowicz, Skarżyński, 2013).

Problemy, jakie podejmowano w polskiej literaturze przedmiotu, dotyczą m.in. stylów radzenia sobie ze stresem słyszących rodziców niesłyszących dzieci. Ojcowie uzyskali w nich wyniki wskazujące na przeciętne nasilenie stresu (w odniesieniu do norm dla populacji polskiej), rzadsze niż matki stosowanie stylu radzenia sobie ze stresem poprzez skoncentrowanie na emocjach (co jest zgodne z normami dla kobiet i mężczyzn) oraz rzadsze niż matki preferowanie stylu unikającego w postaci poszukiwania kontaktów 
towarzyskich oraz angażowania się w czynności zastępcze (Kobosko, 2011a). J. Kobosko w swoich badaniach uzyskała również ciekawy wynik wskazujący, że ojcowie dzieci z uszkodzeniem słuchu posługują się zadaniowym stylem radzenia sobie $\mathrm{z}$ sytuacjami trudnymi niezależnie od rodzaju samooceny, czym różnią się od ojców dzieci słyszących, u których zachodzi związek samooceny z zadaniowym stylem radzenia sobie ze stresem. Niezależnie natomiast od tego, czy dziecko słyszy, czy jest niesłyszące, im mają niższą samoocenę ich ojcowie słyszący, z tym większym prawdopodobieństwem stosują oni emocjonalny styl radzenia sobie ze stresem. Samoocena i radzenie sobie ze stresem u ojców nie wykazuje zmienności ze względu na płeć i wiek dziecka niesłyszącego oraz czas, jaki upłynął od diagnozy niepełnosprawności słuchowej (Kobosko, 2013b).

Wyniki wielu badań wskazują, że typ protezy słuchowej, tj. konwencjonalny aparat słuchowy vs. implant ślimakowy, z jakiej korzysta dziecko niesłyszące, nie ma wpływu na psychiczne funkcjonowanie rodziców (Kobosko, 2013b, s. 39). W badaniach Zaczyńskiej (2001) okazało się, że słyszący ojcowie dzieci z uszkodzeniem słuchu nie różnią się poziomem depresyjności od ojców dzieci słyszących, jednak większe nasilenie depresyjności odnotowano u ojców, którzy porozumiewali się z dzieckiem głuchym w języku fonicznym w porównaniu z tymi, którzy używali do komunikacji język migowy.

Ojciec słyszący, jeśli dziecko z jakiegoś powodu jest migające (np. wskutek porażki w implantowaniu), może napotykać na większe trudności w komunikacji z dzieckiem niesłyszącym niż ojciec niesłyszący, dla którego język migowy jest wspólnym językiem z językiem dziecka, przekazuje go więc w naturalny sposób i modyfikuje zależnie od potrzeb i możliwości rozwojowych małego człowieka (Kotowicz, 2020). Ponadto, dziecku łatwiej jest budować poczucie własnej tożsamości i wartości, akceptacji siebie i wiary w sukces życiowy, gdy jego rodzice są tacy sami jak ono. Ojciec słyszący nie dysponuje zwykle wystarczającym zasobem znaków migowych, aby wyjaśniać dziecku trudne kwestie, interpretować rzeczywistość, prowadzić z nim dłuższe rozmowy na poważne lub abstrakcyjne tematy (Trębicka-Postrzygacz, 1999). Trudności ojca w werbalizacji swoich problemów i emocji w sposób przystępny dla dziecka mogą skutkować tym, że ono samo będzie napotykać na bariery w wyrażaniu własnych przeżyć. Istotny jest również sposób komunikacji między słyszącymi rodzicami dziecka niesłyszącego oraz związane z tym emocje. Im lepsza jest jakość relacji matki z ojcem, wzajemna werbalizacja emocji, tym wyższe są kompetencje językowe ich dziecka i bardziej dojrzały rozwój osobowości (Kobosko, 2009, s. 337, 338). 


\section{WYBRANE PROBLEMY FUNKCJONOWANIA \\ OJCÓW DZIECI NIESŁYSZĄCYCH \\ PODEJMOWANE W LITERATURZE ZAGRANICZNEJ}

Już w 1982 r. M. Crowley, K. Keane i Ch. Needham zwrócili uwagę, że ojcowie są zapomnianymi rodzicami dzieci niesłyszących, ciągle pomijanymi - nie tylko w badaniach i publikacjach. Chociaż upłynęło już kilkadziesiąt lat, badania ojców dzieci z uszkodzeniem słuchu są nadal stosunkowo rzadkie w literaturze surdopedagogicznej, a jeśli są prowadzone, to koncentrują się na etapie wczesnej interwencji. Rzadziej dotyczą ojcostwa wobec dziecka w wieku szkolnym (Hintermair, Sarimski, 2019). Większość badań w literaturze zagranicznej, podobnie jak w polskiej, odnosi się do rodziców, ale grupą badaną są matki, a wyniki są ekstrapolowane na ojców lub też ojcowie stanowią małą liczebnie część grupy badanej, np. w badaniach testowych na 39 rodzin z dzieckiem niesłyszącym było 38 matek i 1 ojciec, a w grupie kontrolnej - 39 matek i 2 ojców (Blank, i in. 2020). Podobnie w badaniach australijskich w grupie 247 rodziców dzieci niesłyszących tylko $10 \%$ stanowili ojcowie (Punch, Hyde, 2011). W badaniach jakościowych również proporcja ojców jest dużo mniejsza niż matek, np. w wywiadach 11 rodziców 8 dzieci niesłyszących w wieku 1-14 lat wzięło udział 8 matek i 3 ojców (Szarkowski, Brice, 2016). Większość badań, która odnosi się do rodziców, traktuje ich jako „grupę rodzinną”, bez uwzględniania różnic między matkami i ojcami, nawet bez podania liczby uczestniczących matek i ojców, np. w artykule analizującym podejmowanie decyzji przez 83 rodziców co do wyboru sposobu komunikacji dla ich niesłyszącego dziecka brak informacji specyfikującej płeć rodzica (Yuelin, 2003).

\section{WAŻNOŚĆ OBECNOŚCI OJCA W WYCHOWANIU DZIECKA}

Liczne dotychczasowe badania w grupie ojców dzieci niesłyszących wskazywały na bardzo ważną rolę taty w życiu dziecka. R. Calderon, S. Low (1998) badały wpływ obecności lub nieobecności ojca na rozwój poznawczy i mowy 22 dzieci niesłyszących w wieku 43-83 miesięcy. Dzieci te ukończyły program wczesnej interwencji w Seattle trwający od 9 do 47 miesiąca ich życia. Badania wykazały, że dzieci, których ojciec jest obecny w rodzinie, mają znacznie lepsze wyniki w zakresie rozwoju językowego oraz związanych z nim osiągnięć poznawczych niż dzieci bez ojca. Wcześniejsze studia 
wykazywały, że ojcowie są mniej niż matki zaangażowani w opiekę nad dzieckiem niesłyszącym, mają mniej motywacji i większe trudności w uczeniu się alternatywnych metod komunikacji z nim (Meadow-Orlans, 1990). Raport Gallaudet wykazał, że tylko 37\% ojców w porównaniu z $67 \%$ matek oceniło swoje zdolności używania języka migowego oraz różnych znaków porozumiewania się z dzieckiem niesłyszącym jako dobre i bardzo dobre (Meadow-Orlans, i in., 1997).

\section{WYZWANIA WCZESNEJ DIAGNOZY USZKODZENIA SŁUCHU U DZIECKA}

Radzenie sobie z diagnozą niedosłuchu dziecka zmieniło się wraz z rozpoczęciem badań przesiewowych u noworodków, gdyż zmienił się model diagnozowania - z zainicjowanego przez zaniepokojonych rodziców do zainicjowanego przez instytucję. Obecnie radzenie sobie z tym problemem zaczyna się bez żadnego przygotowania i bez okresu, w którym rodzice moga nacieszyć się swoim dzieckiem i nawiązać z nim więź bez świadomości, iż „z dzieckiem jest coś nie tak”. Brakuje czasu na to, by rodzice „cieszyli się” swoim dzieckiem jako „normalnym”. Model żałoby, oparty na doświadczeniu śmierci, a stosowany do opisania reakcji rodziców na diagnozę niedosłuchu, może nie być właściwy, gdyż dziecko wciąż jest z nimi i żałoba po jego stracie jako „normalnego” dziecka może być przewlekła. Brak uznania natury tego procesu naraża rodziców na niezrozumienie i brak wsparcia (Kurtzer-White, Luterman, 2003).

Wychodząc od podejścia fenomenologicznego, badacze belgijscy ${ }^{5}$ stwierdzili, że bardzo wczesna diagnoza uszkodzenia słuchu u dziecka niezwykle istotna z punktu widzenia medycznego i „technologicznego” (wczesnej interwencji, aparatowania) dla rodziców powoduje takie osobiste i społeczne implikacje, że wczesność diagnozy nie jest dla nich tak jednoznacznie pozytywna. Ich rodzicielstwo bowiem od samego początku zostaje naznaczone piętnem upośledzenia dziecka, a ono samo zaraz po urodzeniu etykietowane jest jako „z problemem”. W procesie stawania się rodzicem reprezentacja głuchoty jako upośledzenia jest wtedy wszechobecna (Bosteels, Van Hove, Vandenbroeck, 2012).

\footnotetext{
${ }^{5}$ Badania prowadzono we flamandzkim regionie Belgii, który jako jeden z pierwszych na świecie wprowadził badania przesiewowe wszystkich noworodków pod kątem uszkodzeń słuchu.
} 
Analiza jakościowa badań czterech grup fokusowych (33 profesjonalistów) oraz sześciu częściowo strukturyzowanych wywiadów z rodzicami niemowląt i małych dzieci niesłyszących została przeprowadzona zgodnie $\mathrm{z}$ teorią ugruntowaną. Wykazała ona, że głównym kodem teoretycznym wskazującym na problem rodziców małych dzieci niesłyszących było „szukanie równowagi" w rodzicielstwie. Rodzice ci przyjmowali trzy role: (1) bycie rodzicem, co wymagało modyfikacji stylu rodzicielstwa z powodu uszkodzenia słuchu u dziecka, (2) bycie mediatorem, polegające na modulowaniu i „filtrowaniu" interakcji między dzieckiem niesłyszącym a jego otoczeniem, oraz (3) bycie nawigatorem, czyli zarządzanie logistyką procesu leczenia i edukacji. Dla rodziców słyszących diagnoza uszkodzenia słuchu u dziecka wymaga zmian w wielu dziedzinach rodzicielstwa. Wsparcie w każdej z nich jest kluczowe, aby przywrócić poczucie równowagi, a tym samym podnieść jakość ich życia (Vukkadala, i in. 2019).

Spostrzeżenia Vukkadali i współautorów mają na celu pogłębienie zrozumienia dla przeżyć rodziców, natomiast nie kwestionują niepodważalnych ogromnych korzyści, jakie niesie za sobą program przesiewowych badań słuchu u noworodków. To jeden z głównych filarów sukcesu w nauce języka dzieci z uszkodzeniami słuchu, a tym samym sukcesu ich rozwoju psychicznego, społecznego funkcjonowania, jak również dobrostanu rodziców. Chodzi jedynie o to, aby uwrażliwić profesjonalistów oraz osoby bliskie rodzicom, że wczesna diagnoza „naznacza” rodzicielstwo od samego początku „problemem”, który trzeba rozwiązywać poprzez podejmowanie szeregu trudnych decyzji, zaangażowanie czasu i sił psychicznych, korzystanie z usług medycznych, konieczność dokształcania się samych rodziców. Medykalizacja rodzicielstwa naraża ich na konsekwencje błędów jatrogennych i zwiększa obciążenie odpowiedzialnością za decyzje i działania podejmowane względem dziecka. Ta profesjonalizacja rodzicielstwa może zaburzać proces kształtowania się bezpiecznego przywiązania u dziecka oraz więzi rodziców z nim.

Wielu surdopedagogów podkreśla konieczność udostępnienia języka dziecku ze zdiagnozowanym ubytkiem słuchu już od pierwszych dni i tygodni życia. Mózg dziecka jest chłonny i potrzebuje przyswajać znaki ułatwiające rozumienie świata, dlatego nie można czekać na efekty implantu ślimakowego, ale ćwiczyć z dzieckiem język migowy ${ }^{6}$. Cała rodzina musi się

\footnotetext{
${ }^{6}$ Grupa badaczy reprezentująca ośrodki z USA (m.in. Department of Psychology, Gallaudet University, Washington, DC, USA) i jedna osoba z Niemiec (Deaf Studies and Sign Language Interpreting, Humboldt-Universität, Berlin, Germany) określają swoje stanowisko jako promowanie „bimodal-bilingualism” (bimodalnej dwujęzyczności/dwujęzyczności bimodalnej. Twierdzą, że mowa jest dostępna tylko dla niektórych dzieci niesłyszących, w tym z implantem ślimakowym,
} 
uczyć jednocześnie tego języka, tak jak uczy się dziecko niesłyszące. Nawet umiarkowana płynność języka migowego w rodzinie jest dla dziecka bardzo korzystna. Wspólna jego nauka może być jednym z najsilniejszych doświadczeń kształtujących więź między członkami rodziny oraz wzmacniającym przywiązanie na linii rodzice-dziecko (Humphries i in., 2019). Dla ojca, który ma mniej niż matka możliwości tworzenia z dzieckiem wczesnej i bardzo bliskiej więzi emocjonalnej, zdobycie umiejętności posługiwania się językiem migowym oraz porozumiewania się za pomocą różnych znaków z dzieckiem jest szczególnie ważne, gdyż wzmacnia poczucie kompetencji ojcowskiej, zmniejsza lęk przed dzieckiem, ułatwia bliski kontakt i dostarcza ojcu pozytywnych wzmocnień.

\section{PRZEŻYCIA I POSTAWY OJCA WOBEC DZIECKA}

Badania typu jakościowego wywiadem częściowo ustrukturyzowanym, przeprowadzone w Brazylii odnośnie do doświadczenia życiowego związanego z byciem ojcem dziecka niesłyszącego, wykazały zróżnicowanie uczuć i reakcji ojców. W wywiadach pojawiły się takie reakcje, jak np. „znieruchomienie", pasywność, bezsilność, słabość, poczucie kruchości, smutek, a także brak wewnętrznych zasobów do stawienia czoła nowej sytuacji i radzenia sobie z nią. Upływ czasu oraz interakcje z dzieckiem były ważnymi czynnikami, które przyczyniły się do powstania nowego znaczenia głuchoty i akceptacji dziecka przez ojców (Cortelo, Françozo, 2014).

Reakcje emocjonalne rodziców (np. uczucia smutku i żalu) zależą od etapu adaptacji do sytuacji bycia rodzicem dziecka z uszkodzeniem słuchu, np. jest silniejsze przed implantowaniem i do dwóch lat po nim. W grupie ojców do dwóch lat po wszczepieniu implantu ślimakowego u ich dziecka istotnie częściej niż u matek stwierdzono stosowanie mechanizmu obronnego, jakim jest zaprzeczanie przeżyciom związanym z zaistniałą sytuacją (Anagnostou, Graham, Crocker, 2007).

Implantowanie w dłuższej perspektywie czasowej ma znaczenie dla pozytywnej oceny przez ojców psychospołecznego przystosowania dziecka nie-

podczas gdy znaki (wzrokowe lub dotykowe) są dostępne dla wszystkich dzieci niesłyszących. Implantowanie nie gwarantuje opanowania mowy, nawet przy usilnych staraniach rodziców. Dlatego autorzy twierdzą, że nauka języka migowego w rodzinie dziecka niesłyszącego jest ważnym czynnikiem więziotwórczym od jego urodzenia, a nawiązane pozytywne interakcje odgrywają kluczową rolę w nauce języka i rozwoju psychicznym dziecka, niezależnie od modalności językowej (Humphries i in., 2019). 
słyszącego, jego funkcjonowania w rodzinie i w szkole. J. Nicholas i A. Geers (2003) otrzymały interesujące wyniki badań ojców 181 dzieci, którym wszczepiono implant ślimakowy przed co najmniej czterem laty. Ojcowie i matki byli ogólnie zadowoleni z pozytywnego wpływu implantacji na życie ich dziecka i ich rodziny, jednak to zadowolenie było istotnie związane z osiągnięciami dziecka w zakresie mowy i języka. Oceny rodziców dotyczące psychospołecznej adaptacji dziecka były również wyższe w odniesieniu do tych dzieci, które miały dłużej implant, wobec dziewcząt niż chłopców, wobec dzieci bardziej niż mniej inteligentnych oraz wobec dzieci uczęszczających do szkoły prywatnej w przeciwieństwie do szkół publicznych.

\section{ZAANGAŻOWANIE OJCOWSKIE}

Zaangażowaniu ojcowskiemu poświęcone były badania przeprowadzone przez S. Ingber i T. Most (2012). Objęły one grupę 38 ojców przedszkolaków z uszkodzeniem słuchu oraz 36 ojców przedszkolaków z prawidłowym słuchem. W ich wyniku stwierdzono podobnie wysoki poziom zaangażowania ze strony obu grup ojców. Zaangażowanie korelowało dodatnio z deklarowanym przez rodziców poczuciem własnej skuteczności rodzicielskiej, spójnością rodziny i zdolnością przystosowawczą, a także relacjonowanym przez matkę zaangażowaniem ojca w życie dziecka. Badania te wskazały na potrzebę wspierania przez matki zaangażowania mężów w opiekę i wychowanie dziecka niesłyszącego oraz wzmacniania ich poczucia kompetencji, gdyż ono motywuje ojców do większego poświęcenia się na rzecz dziecka.

Ojcowie, jak pokazały badania, byli znacznie mniej zaangażowani we wczesną interwencję i wspomaganie swojego dziecka niż matki, co przejawiało się mniejszym zainteresowaniem, rzadszą obecnością na zajęciach i ogólnie słabszą współpracą ze specjalistami. Zaangażowanie ojców było natomiast pozytywnie związane z poczuciem sprawstwa i skuteczności oraz nieformalnym i formalnym wsparciem społecznym (Zaidman-Zait i in., 2018). W przypadku rodziców dzieci niesłyszących poczucie własnej skuteczności odnosi się nie tylko do ogólnego przekonania o zdolności do kompetentnego funkcjonowania w roli rodzica dziecka, ale również do radzenia sobie ze specjalnymi potrzebami edukacyjnymi, jakie powoduje uszkodzenie słuchu, np. umiejętność współpracy z profesjonalistą w ramach wczesnej interwencji, dbanie o pomoce sensoryczne lub wspieranie rozwoju języka dziecka. Poczucie sprawstwa jest pozytywnie skorelowane ze zmniejszonym stresem 
rodzicielskim i akceptacją dziecka. Ojcowie zaangażowani w zajęcia związane $\mathrm{z}$ wczesną interwencją lepiej radzili sobie z konsekwencjami, jakie wniosła niepełnosprawność dziecka w ich życie (Zaidman-Zait i in. 2016).

Wyniki badań kwestionariuszowych rodziców dzieci niesłyszących, jakie otrzymali Hintermair i Sarimski (2019), wskazały, że ojcowie dzieci niesłyszących nie uczestniczą regularnie w spotkaniach związanych z wczesną interwencją. Uwidoczniły też silny związek między poczuciem skuteczności, postrzeganym wsparciem ze strony poradni wczesnej interwencji i zaangażowaniem w działania terapeutyczne. Ojcowie, którzy doświadczali więcej wsparcia ze strony profesjonalistów prowadzących wczesną interwencję, czuli się bardziej kompetentni we wspieraniu rozwoju ich dziecka. Usługi wczesnej interwencji powinny umożliwiać ojcom jak największy udział w sesjach, gdyż zaangażowanie we wczesną interwencję ma duże znaczenie dla ich upodmiotowienia jako ojców dzieci z uszkodzeniem słuchu i sprawowania roli ojca. Upodmiotowienie związane jest z odkrywaniem własnych możliwości, odzyskaniem motywacji, energii i wyobraźni do kształtowania swojej sytuacji życiowej, braniem swoich spraw we własne ręce, docenianiem osobistych dokonań.

A. Szarkowki i E. Dirks (2019-2020) zaanonsowały prowadzenie badań w ramach projektu pt. „Przekonania, pragnienia i wyzwania ojców i matek wychowujących małe dziecko z uszkodzeniem słuchu". Obejmuje on trzy obszary: przegląd literatury przedmiotu, zaangażowanie i poczucie własnej skuteczności, interakcja na linii rodzic-dziecko. W ramach tegoż projektu przygotowywane jest opracowanie na temat „Rodzicielska skuteczność, rodzicielskie zaangażowanie ojców i matek dzieci z uszkodzeniem słuchu”. Uczestnikami badań są holenderscy ojcowie i matki 30 dzieci niesłyszących uczestniczący w programie wczesnej interwencji.

\section{STRES RODZICIELSKI OJCÓW DZIECI NIESŁYSZĄCYCH}

Wychowywanie dzieci z uszkodzeniami słuchu stanowi wyjątkowe i całożyciowe wyzwanie, które może narazić rodziców na większe ryzyko podwyższonego poziomu stresu rodzicielskiego. Większość badań wskazuje, że słyszący rodzice dzieci z uszkodzeniami słuchu przeżywają zwiększony stres w porównaniu z rodzicami dzieci z prawidłowym słuchem (Zaidman-Zait, 2008).

W badaniach prowadzonych przez K. Meadow-Orlans (1994) - 20 matek i 16 ojców niemowląt (średnia wieku 2,8 miesiąca), u których zdiagnozo- 
wano uszkodzenie słuchu, oraz 20 matek i 15 ojców, których niemowlęta miały prawidłowy słuch - okazało się, że stres rodzicielski u matek i ojców niesłyszących niemowląt był silniejszy niż u rodziców dzieci słyszących, natomiast wsparcie społeczne było $\mathrm{w}$ ich grupie związane $\mathrm{z}$ niższym poziomem stresu rodzicielskiego i miało dla nich większe znaczenie ochronne niż dla rodziców niemowląt słyszących.

\section{KONTEKSTOWY CHARAKTER STRESU RODZICIELSKIEGO}

W badaniach rodziców 181 dzieci głuchych i 92 dzieci z prawidłowym słuchem zauważono, że poziom stresu rodzicielskiego $\mathrm{w}$ rodzinach $\mathrm{z}$ dzieckiem niesłyszącym jest wyższy, ale ma charakter bardziej kontekstowy niż ogólny, tzn. jest związany z opóźnieniami językowymi oraz nieprawidłowymi zachowaniami dziecka, te zaś są zależne od stopnia utraty słuchu i faktycznej możliwości słyszenia przez dziecko. Istotne różnice w stresie stwierdzono w badaniach jedynie w odniesieniu do miar, które odnosiły się do specyficznych problemów związanych z niepełnosprawnością dziecka, a nie do ogólnej miary stresu. Największe wyzwania stojące przed rodzicami dzieci niesłyszących to: trudności komunikacyjne, obawy dotyczące edukacji i przyszłości dziecka, konserwacja aparatów słuchowych i konieczność bycia nauczycielem mowy dla swojego dziecka (Quittner i in., 2010).

Również Lederberg i Golbach (2002) sformułowali podobny wniosek, że rodzice dzieci niesłyszących częściej doświadczają stresu w obszarach specyficznych dla niepełnosprawności ich dziecka, a trudności w komunikacji z nim są dla nich głównym czynnikiem stresogennym. Podobnie Barker i współpracownicy (2009) na podstawie badań grupy 188 rodziców dzieci niesłyszących w wieku do 5 lat, przygotowywanych do wszczepienia implantu ślimakowego stwierdzili, że głównym czynnikiem stresogennym są trudności językowe dziecka, a tym samym trudności w komunikacji z nim.

\section{STRES OJCÓW DZIECI Z USZKODZENIEM SŁUCHU I Z INNYMI NIEPEŁNOSPRAWNOŚCIAMI}

T. Mavrogianni i V. Lampropoulou z University of Patras w Grecji (2020) przeprowadziły badanie ankietowe 172 ojców dzieci w wieku przedszkolnym. Wśród nich było 25 ojców dzieci niesłyszących, 23 ojców dzieci z nie- 
pełnosprawnością intelektualną, 30 ojców dzieci z zaburzeniami ze spektrum autyzmu i 94 ojców dzieci pełnosprawnych. Wyniki nie wykazały różnic w ogólnym poziomie zaangażowania w opiekę nad dziećmi między ojcami dzieci niesłyszących a ojcami z pozostałych grup. Stres ojców dzieci niesłyszących był niższy niż ojców dzieci z zaburzeniami ze spektrum autyzmu lub dzieci z niepełnosprawnością intelektualną, ale większy stres w porównaniu z ojcami dzieci pełnosprawnych. Satysfakcja małżeńska była czynnikiem, który najsilniej wpływał na zaangażowanie ojców w życie ich dzieci niesłyszących, co oznacza, że ojcowskie zaangażowanie jest zależne od satysfakcjonujących relacji z żoną.

Rodzice dzieci niesłyszących, które mają dodatkowe upośledzenia, są szczególnie zestresowani. Istotny wpływ na doświadczenia stresowe obojga rodziców i - w opinii ojców - na rozwój psychiczny dziecka mają jego kompetencje komunikacyjne. Ponadto, kompetencje te mają większe znaczenie w przewidywaniu poziomu funkcjonowania dziecka oraz poziomu stresu obojga rodziców niż sam sposób porozumiewania się (język mówiony lub migowy) (Hintermair, 2006).

\section{STRES RODZICIELSKI OJCÓW I MATEK DZIECI NIESŁYSZĄCYCH}

Badania porównujące stres rodzicielski między matkami i ojcami w ich własnych ocenach dały mieszane wyniki. A. Zaidman-Zait i współpracownicy (2016) na podstawie obszernego przeglądu badań stwierdzili, że wyniki badań nad stresem matek nie powinny być uogólniane na grupę ojców z uwagi na większą rolę matki w codziennej opiece nad dzieckiem niesłyszącym oraz w jego wychowaniu i rehabilitacji. Niektóre badania wskazują na wyższy poziom stresu matek niż ojców, inne na porównywalny, jeszcze inne na mniejszy. Wyniki badań zależą od pytań badawczych, wielu zmiennych związanych z metodologią badań i cech grupy badanej. Na podstawie analizy dotychczasowych oraz własnych badań matek dzieci niesłyszących Pipp-Siegel, Sedey i Yoshinaga-Itano (2002) stwierdziły, że różnice w badaniach stresu rodzicielskiego i związanych z nim komponentów psychicznych zależą od wielkości próbki, rodzaju narzędzi badawczych i obliczeń statystycznych, wieku dzieci oraz stopnia ubytku słuchu.

W badaniach K. Meadow-Orlans z roku 1995 na grupie słyszących rodziców 20 niesłyszących lub słabo słyszących 9-miesięcznych niemowląt otrzymano wyniki wskazujące na podobny poziom stresu między matkami i ojca- 
mi, jednak matki częściej niż ojcowie postrzegały swoje niemowlęta jako „rozpraszające”, przejawiały więcej objawów depresyjnych i zgłaszały częściej negatywne relacje małżeńskie. Matki tych dzieci wykazywały większy stres życiowy w porównaniu z matkami niemowląt słyszących, szczególnie w odniesieniu do sfery finansów i pracy zawodowej (Meadow-Orlans, 1995) ${ }^{7}$. Natomiast z kolejnych badań K. Meadow-Orlans, B. Dyssegaard, S. SmithGray (2004) wynika, że uszkodzenie słuchu jest wprawdzie mniej stresujące dla ojców niż matek, ale w rzeczywistości stres ma niekorzystny wpływ również na życie ojców.

$\mathrm{W}$ badaniach prowadzonych $\mathrm{w}$ sektorze arabskim w Izraelu na grupie 60 rodziców (30 par matka-ojciec) mających dzieci niesłyszące w wieku 3-8 lat nie wykazano istotnych różnic między matkami i ojcami w zakresie stresu rodzicielskiego, akceptacji dziecka i systemów wsparcia rodzicielskiego. Oboje rodzice zgłaszali podobny, umiarkowany poziom stresu rodzicielskiego w kontekście bycia rodzicem dziecka z uszkodzeniem słuchu, jednak ojcowie uzyskali wyższe wyniki (w skali od 1 do 4 średnia dla matek wynosiła 1.78, dla ojców 2.15). Wynik okazał się podobny do badań Meadow-Orlans z 1994 r., a jednocześnie potwierdził się mechanizm „spillover”, polegający na wpływie stresu jednego z rodziców na stres drugiego. Płynie stąd wniosek, że procesy interpersonalne w rodzinie powinny być przedmiotem znacznie głębszej penetracji badawczej. W relacjonowanych badaniach matki miały jednak istotnie wyższe niż ojcowie poczucie własnej skuteczności i samodzielności w opiece nad swoim dzieckiem niesłyszącym (Zaidman-Zait i in. 2016).

W analizie badań nad funkcjonowaniem ojców dzieci niesłyszących należy podkreślić znaczenie czynników kulturowych, co uwidoczniły m.in. badania rodziców z arabskiego sektora w Izraelu, którzy różnią się od reszty społeczeństwa tradycjami rodzinnymi, systemem norm i wartości, postawami. $\mathrm{W}$ tej grupie rodziców to matki są odpowiedzialne za opiekę, wychowanie i rehabilitację dziecka, dzięki czemu zyskują wyższe wyniki w radzeniu sobie ze stresem sytuacji, natomiast ojcowie ujawniają uczucia wstydu za dziecko i unikają pojawiania się z nim w miejscach publicznych. Chociaż w domu ojciec podejmuje wszystkie ważne decyzje, to jednak matka jest odpowiedzialna za troskę o dziecko niesłyszące (Zaidman-Zait, i in. 2016). Kontekst

\footnotetext{
${ }^{7}$ Wyniki ogólnokrajowych badań starszych dzieci niesłyszących (w wieku 6-7 lat) oraz ich rodziców (80 wywiadów pogłębionych) prowadzone przez trzy uczone z uniwersytetu Gallaudet w Waszyngtonie dają szczególny wgląd w funkcjonowanie matek i ojców dzieci niesłyszących (Meadow-Orlans, Mertens, Sass-Lehrer, 2003).
} 
kulturowy ma związek z przeżyciami ojca i matki, obowiązkami rodzicielskimi, rodzajem i zakresem otrzymywanego wsparcia, a to wszystko ma znaczenie nie tylko dla funkcjonowania każdego z nich, ale także dziecka niesłyszącego.

\section{ROLA ZASOBÓW OSOBISTYCH RODZICÓW}

W badaniach M. Hintermair (2006) prowadzonych w Bawarii grupie rodziców dzieci z uszkodzeniem słuchu przekazano kwestionariusze z wyraźną prośbą, aby oboje rodzice wypełnili je niezależnie od siebie. Odsetek odpowiedzi wyniósł $35,5 \%$. Do analiz wykorzystano 213 par kwestionariuszy wypełnionych zarówno przez matki, jak i ojców dzieci niesłyszących. Umożliwiło to rzetelne porównanie doświadczeń obojga rodziców. Otrzymane wyniki wskazały, że waga zasobów osobistych rodziców, a zwłaszcza wysokiego poczucia koherencji (nieco niższe wartości dla ojców), jest nie do przecenienia, gdyż związane są one z pozytywnym nastawieniem do życia i radzeniem sobie z konsekwencjami uszkodzenia słuchu u dziecka (też: Hintermair, 2004). Rodzice, którzy mają wysokie poczucie koherencji, a także są przekonani, że posiadają niezbędne kompetencje do wychowania dziecka niesłyszącego, wykazują znacznie niższe wyniki w zakresie stresu. Równie ważne są szczególne kompetencje w postępowaniu z dzieckiem niesłyszącym. Oba komponenty zasobów osobistych mają również pośredni wpływ na rozwój społeczno-emocjonalny dziecka.

\section{ROLA WSPARCIA SPOŁECZNEGO}

Osobiste i społeczne możliwości radzenia sobie ze stresem decydują o adaptacji rodzin do różnych wyzwań związanych $z$ ubytkiem słuchu u dziecka. Dlatego też nasilenie stresu oraz rodzaj i poziom uzyskiwanego wsparcia stał się jednym z problemów, które są przedmiotem badań w grupie ojców dzieci niesłyszących (również w porównaniu z matkami). W badaniach $\mathrm{z}$ tego zakresu uwaga jest zwykle skoncentrowana na badaniu wsparcia kierowanego do obojga rodziców, a nie tylko do jednego z nich. Stwierdzono duże zaangażowanie rodziny i przyjaciół w udzielanie wsparcia informacyjnego, materialnego i emocjonalnego, aby ułatwić rodzicom radzenie sobie z problemami, jakie stwarza wychowanie dziecka z uszkodzeniem słuchu (Zaidman-Zait, 2007). Analiza korelacji wyników badań izraelskich wykaza- 
ła, że większe wysiłki skierowane na radzenie sobie ze stresem rodzicielskim poprzez uzyskiwane wsparcie obniżyły poziom tego stresu. Rola wsparcia jest więc nie do przecenienia $\mathrm{w}$ radzeniu sobie ze stresem i jego skutkami (Zaidman-Zait $\mathrm{i}$ in., 2016).

Dla rodziców dzieci niesłyszących ważne jest nie tyle ogólne wsparcie społeczne zmniejszające napięcie emocjonalne, dystres, co wsparcie specyficzne, dostosowane do sytuacji konkretnej rodziny, czyli wsparcie od przyjaciół, znajomych, dziadków, innych rodzin z dziećmi niesłyszącymi oraz specjalistów. Wartość tego zindywidualizowanego wsparcia ma większe znaczenie dla ojców niż matek i przynosi wielką ulgę w zmaganiu się z doświadczeniami codzienności, zwłaszcza w zakresie interakcji rodzic-dziecko (Hintermair, 2006).

Jak potwierdziły badania prowadzone przez K. Åsberg, J. Vogel, C. Bowers (2008), rodzice dzieci, które używają jedynie języka migowego, zgłaszali większe wsparcie, natomiast rodzice dzieci używających komunikacji totalnej wykazywali mniej stresu. Inaczej mówiąc, wsparcie społeczne i sposób komunikacji były istotnymi predyktorami stresu rodzicielskiego oraz satysfakcji życiowej. Rodzice dzieci z implantami nie różnili się pod względem stresu rodzicielskiego i wsparcia społecznego w porównaniu z rodzicami dzieci bez implantów. Wyższy poziom postrzeganego wsparcia społecznego korelował z niższym poziomem stresu wśród rodziców oraz z ich satysfakcją życiową.

Zdaniem M. Hintermair (2006), ze względu na dużą zgodność kluczowych zmiennych badanych w odniesieniu do 213 par matek i ojców dzieci niesłyszących różnice były raczej marginalne i nie wskazywały na istotność w szerszym obszarze funkcjonowania rodzicielskiego, dlatego można planować oddziaływania psychopedagogiczne kierowane do rodziców bez konieczności ciągłej specyfikacji rodzaju wsparcia lub udzielanej pomocy.

\section{STRES RODZICIELSKI A ROZWÓJ DZIECKA NIESŁYSZĄCEGO}

Badania przeprowadzone przez A. Hadadian (1995) objęły 30 dzieci z uszkodzeniem słuchu w przedziale wiekowym od 20 do 60 miesięcy i ich rodziców słyszących. W grupie dzieci niesłyszących nie stwierdzono różnic w ocenie przywiązania do matki lub ojca, natomiast wystąpiły one w badaniach dorosłych, tzn. wyraźne różnice wystąpiły w relacjach matka-dziecko i ojciecdziecko. Ponadto stwierdzono negatywne korelacje między postawą rodzi- 
ców wobec głuchoty a bezpiecznym przywiązaniem dzieci niesłyszących. Związek między postawami rodziców wobec niepełnosprawności słuchowej ich dzieci a relacją przywiązania stanowi kolejny dowód na krytyczną rolę wczesnej interwencji w rozwoju dzieci o specjalnych potrzebach oraz na konieczność włączania ojców w programy wczesnej interwencji.

Stres rodzicielski jest czynnikiem prognostycznym wyników rozwojowych u dzieci niesłyszących (jak i z prawidłowym słuchem). Jednak nie jest jasne, w jaki sposób stres rodzicielski ma związek z zagrożeniami rozwoju mowy tych dzieci i negatywnych wyników neurokognitywnych. $Z$ badań grupy uczonych $z$ The Ohio State University oraz Indiana University w USA, które objęły grupę 39 dzieci z uszkodzonym i 41 dzieci z normalnym słuchem oraz ich opiekunów, wynika, że poziomy stresu rodzicielskiego nie różniły się istotnie między obiema grupami rodziców. Zauważono jednak istotny negatywny związek między stresem rodzicielskim a rozumieniem języka u dzieci z uszkodzonym słuchem oraz ich zdolnością do kontroli i hamowania impulsów. Wzrost stresu rodzicielskiego wiązał się z niższymi wynikami rozumienia języka i kontroli hamowania u dzieci niesłyszących (Blank, i in. 2020).

Również w badaniach holenderskich grupy 30 małych dzieci (średnia wieku 27,4 miesiąca) z umiarkowanym ubytkiem słuchu i 30 dzieci słyszących oraz ich rodziców okazało się, że gorsze funkcjonowanie społeczno-emocjonalne i zdolności językowe dziecka wiązały się z wyższym poziomem stresu u rodziców. Rodzice, którzy doświadczyli mniejszego wsparcia społecznego, zgłaszali wyższy poziom stresu. Biorąc pod uwagę, że stres rodzicielski jest związany z gorszym funkcjonowaniem dziecka, już w ramach wczesnej interwencji powinien on być identyfikowany a rodzicom udzielana odpowiednia pomoc (Dirks, Uilenburg, Rieffe, 2016).

Barker i współpracownicy (2009) wymienili liczne konsekwencje stresu rodzicielskiego oraz opóźnienia i nieprawidłowości w rozwoju mowy u dzieci niesłyszących na ich ogólny rozwój. Nie wiadomo, co jest przyczyną, a co skutkiem, ale wiadomo, że stres rodzicielski jest związany z występowaniem u dziecka zaburzeń behawioralnych, trudności w regulowaniu swoich emocji, uwagi i zachowania (co jednocześnie dla rodziców jest źródłem większego stresu). Autorzy tych badań identyfikowali takie nieprawidłowości u dzieci, jak: zaburzenia w koncentracji uwagi, nieuwaga; trudności z wyrażaniem swoich potrzeb, co rodzi frustrację; trudności w rozumieniu mowy i poleceń rodziców, a tym samym we współpracy i negatywizm wobec nich rodziców; wybuchy agresji; niższy poziom wytrwałości; krótszy czas zabawy w samot- 
ności; niższe wyniki w rozwiązywaniu problemów w porównaniu z dziećmi słyszącymi. Testowany przez autorów model potwierdził, że deficyty językowe dzieci z ubytkiem słuchu przyczyniają się do powstania ich trudności z utrzymaniem uwagi, z komunikacją w relacji z rodzicami i zaburzeń w zachowaniu.

Uwzględnienie stresu rodzicielskiego w badaniach jest ważne ze względu na jego złożone konsekwencje, ponieważ dotyka on zarówno rodziców, jak i dzieci na różne sposoby. Stres rodzicielski ma wieloaspektowy wpływ na funkcjonowanie dziecka, np. w badaniu grupy 42 rodziców (matek i ojców) dzieci niesłyszących okazało się, że stres ojcowski zwiększał się wraz ze wzrostem statusu zawodowego rodziny i poziomu wykształcenia ojca, natomiast stres macierzyński nie był istotnie związany z tymi zmiennymi. Zarówno w przypadku matek, jak i ojców zwiększony stres związany był ze zgłaszaną przez nauczycieli niedojrzałością emocjonalną dziecka niesłyszącego, natomiast w odróżnieniu od stresu macierzyńskiego, zwiększony stres ojcowski był skorelowany $\mathrm{z}$ deklarowanym przez nauczyciela wycofywaniem się dziecka z nauki, mniej rozwiniętymi umiejętnościami czytania z ruchu warg i niższymi ocenami akceptacji społecznej wśród rówieśników (Hagborg, 1989). Badania A. Hadadian i S. Rose (1991) odnośnie do zależności między postawami rodziców wobec głuchoty a umiejętnościami komunikacyjnymi dzieci z wadą słuchu wykazały, że zachodzą istotne korelacje między punktacją ojców w Skali Postaw wobec Głuchoty a punktacją rozumienia języka przez ich niesłyszące dzieci. Nie stwierdzono natomiast istotnych różnic w postawach między matkami a ojcami.

Również w badaniu kilkoma kwestionariuszami 213 matek i 213 ojców dzieci niesłyszących wykazano, że wysoki poziom stresu rodzicielskiego jest związany z częstymi społeczno-emocjonalnymi problemami u dzieci (Hintermair, 2006). Jeśli chodzi o dziecko, stres rodzicielski zwiększa ponadto ryzyko problemów z zachowaniem (Åsberg, Vogel, Bowers, 2008), zaburzeń w rozwoju języka i w funkcjonowaniu dziecka. Stres rodziców ma również wielorakie konsekwencje dla nich samych, np. zwiększa częstość zaburzeń ich zdrowia psychicznego (Zaidman-Zait i in., 2016) oraz wpływa negatywnie na ich wzajemne relacje, co skutkuje częstszym niezadowoleniem małżeńskim. Ma również wpływ na relacje rodziców z dzieckiem niesłyszącym, powodując zaburzenia w przywiązaniu, mniej pozytywne interakcje na linii rodzic-dziecko (Åsberg, Vogel, Bowers, 2008) oraz zwiększa ryzyko nieprawidłowych zachowań opiekuńczych i trudności w udzielaniu dziecku pomocy (Zaidman-Zait i in., 2016). 
W badaniach 213 par rodziców dzieci z uszkodzeniem słuchu przez M. Hintermair (2006) okazało się, że istnieje związek między stresem rodzicielskim a problemami społeczno-emocjonalnymi dziecka niesłyszącego: rodzice doświadczający mniejszego stresu wychowują dzieci o lepszym rozwoju społeczno-emocjonalnym. Oznacza to, że doświadczenie stresu zarówno przez matkę, jak i ojca ma wysoce istotny związek (u ojca nieco niższy) z relacjonowanymi przez nich problemami społeczno-emocjonalnymi dziecka, tzn. rodzice, którzy czują się bardzo zestresowani, częściej wskazują na takie problemy ich dziecka niesłyszącego, jak: bóle głowy, bóle brzucha, nudności, zamartwianie się, poczucie nieszczęścia, przygnębienie, problemy z zachowaniem (częste napady złości, kłamstwa, kradzieże, nieposłuszeństwo, kłótnie z innymi dziećmi), nadpobudliwość (niepokój, wiercenie się, niemożność pozostania w bezruchu, łatwość rozproszeń), impulsywność, problemy z rówieśnikami (brak popularności, samotność, zaczepianie lub zastraszanie przez inne dzieci). Założenie, że chłopcy niesłyszący mają więcej problemów z zachowaniem niż dziewczęta niesłyszące, zostało potwierdzone jedynie w przypadku opinii matek. Ta różnica wynika $z$ odmiennych kryteriów oceny zachowania dzieci. Ojcowie pewne zachowania oceniane przez matki jako „problematyczne" postrzegają jako właściwe, a nawet pozytywne u chłopców (,stoi na swoim”, „nie zgadza się ze wszystkim”, ,jest żywe”). Autor tych badań podkreśla, że nie można na ich podstawie definitywnie rozstrzygnąć kwestii przyczyny i skutku, jednak liczne dotychczasowe doniesienia teoretyczne i empiryczne potwierdzają hipotezę, że stres rodzicielski jest raczej przyczyną niż skutkiem problemów emocjonalnych i behawioralnych dziecka.

\section{ZDROWIE PSYCHICZNE RODZICÓW DZIECKA NIESŁYSZĄCEGO}

Oceną zdrowia psychicznego rodziców dzieci niesłyszących zajęli się m.in. badacze z Freiburga. W badaniach przekrojowych wzięło udział 52 matki i 42 ojców 55 dzieci z implantem ślimakowym. Wyniki $21 \%$ rodziców wskazywały na dystres psychiczny, objawy niepokoju i psychicznego cierpienia (niezależne od stanu rozwoju językowego dziecka). Średnia jakość życia tych rodziców była niższa w stosunku do normy, chociaż wyższa niż pacjentów chorych somatycznie (Spahn i in., 2004).

Szczególną zmianę w jakości życia rodziców dzieci niesłyszących obserwuje się po implantacji ślimakowej. W pięcioletnich badaniach przekrojo- 
wych 124 matek i ojców 61 dzieci z wadą słuchu, które miały odpowiednio dopasowany pierwszy aparat słuchowy i były poddawane badaniu wstępnemu do implantacji ślimakowej, a następnie korzystały z implantu, okazało się, że przed implantacją samopoczucie i jakość życia rodziców były znacznie obniżone, natomiast wsparcie społeczne i pozytywne nastawienie zmniejszały niepokój. W wyniku leczenia i terapii uzyskano podwyższenie i stabilizację dobrostanu rodziców, którzy mogli prowadzić „,normalne życie codzienne" pomimo uszkodzenia słuchu u dziecka (Burger i in., 2008).

Badania prowadzone $\mathrm{w}$ Turcji, których celem było porównanie rodziców dzieci z $(n=230)$ i bez $(n=230)$ uszkodzenia słuchu pod względem objawów stresu (Lista Kontrolna Samooceny Stresu), depresji (Inwentarz Depresji Becka) i lęku-cechy (Inwentarz Lęku-Cechy) wykazały, że rodzice dzieci niesłyszących, zwłaszcza matki, są narażeni na ryzyko wystąpienia zaburzeń psychicznych i psychiatrycznych. U ojców tego rodzaju problemy ze zdrowiem psychicznym występowały rzadziej (Doğan, 2014). Podobne wyniki uzyskali badacze z Baqiyatallah University of Medical Sciences w Teheranie (Iran). Skoncentrowali się oni na porównaniu lęku, depresji i stresu Skalą Depresji oraz Lęku i Stresu (DASS-21) rodziców dzieci z ciężkim uszkodzeniem słuchu, które przeszły implantację ślimakową. W badaniach przeprowadzonych w latach 2007-2009 uwzględniono dwie grupy rodziców: spokrewnionych (125 par) oraz niespokrewnionych (55 pary). Ponieważ w małżeństwach spokrewnionych wada słuchu występuje częściej, oczekiwano, że pary te będą miały większe problemy psychiczne. W rezultacie tych badań okazało się, że wszyscy rodzice mieli wysoki poziom depresji, lęku i stresu, jednak depresja i lęk były istotnie wyższe wśród rodziców spokrewnionych (odpowiednio $\mathrm{p}=0,001 \mathrm{i} \mathrm{p}=0,005$ ), natomiast poziomy stresu nie różniły się znacząco między dwiema grupami. Matki w porównaniu $\mathrm{z}$ ojcami miały wyższy poziom depresji, lęku i stresu $(p<0,05)$, co jest zgodne $\mathrm{z}$ wynikami innych badań, wskazujących na podatność kobiet w tym zakresie. Narodziny dziecka niesłyszącego mogą być źródłem problemów psychicznych u rodziców, zwłaszcza jeśli są oni spokrewnieni. Ojcowie okazali się bardziej odporni na dysfunkcje psychiczne w takiej sytuacji życiowej. Ich poczucie winy z powodu nieuchronienia rodziny przed „nieszczęściem” okazuje się mniej zagrażające zdrowiu psychicznemu niż poczucie winy matek z powodu urodzenia dziecka z niepełnosprawnością słuchową (Noohi, Ghalamfarsa, Davoudi Monfared, 2018). 


\section{ZAKOŃCZENIE}

Uszkodzenie słuchu u dziecka jest niewątpliwie ciągle trudnym doświadczeniem i wyzwaniem dla rodziców, ale dzięki wczesnej diagnozie oraz wykorzystaniu implantów ślimakowych wiele problemów, z jakimi borykali się rodzice wcześniej, zostaje im obecnie oszczędzonych. Nadal matka jest jednak szczególnie odpowiedzialna za opiekę, wychowanie i edukację dziecka niesłyszącego, dlatego potrzebą chwili jest aktywizacja ojców w zakresie komunikacji z dzieckiem niesłyszącym, kształtowanie warunków do nawiązywania silnej więzi ojcowskiej i wzmocnienia ich w spełnianiu roli rodzicielskiej. Ojcostwo sprawowane wobec dziecka z uszkodzeniem słuchu jest rozwijającym doświadczeniem nie tylko dla dziecka, ale także dla jego ojca i matki oraz jego rodzeństwa. Może dostarczyć każdemu z nich z niczym nieporównywalnych przeżyć wspólnoty rodzinnej, miłości wzajemnej przeżywanej w konkretnych sytuacjach życiowych, więzi, która będzie źródłem siły na całe życie. Wzór silnego psychicznie, zaangażowanego na rzecz rodziny i kochającego ojca będzie dla dziecka niesłyszącego kapitałem na życie, którego znaczenia nie da się przecenić.

Mając jednak na uwadze trudne problemy, z jakimi muszą borykać się rodziny z dzieckiem z niepełnosprawnością słuchową, zwłaszcza wtedy, gdy otrzymują diagnozę, gdy są w procesie leczenia dziecka, gdy rozpoczyna ono edukację szkolną lub ma z nią problemy, gdy dojrzewa, wybiera zawód, osiąga dorosłość i powinno stać się samodzielnym i niezależnym dorosłym rodzice potrzebują nie tylko oparcia ze strony bliskich im osób, ale również profesjonalnej pomocy psychologiczno-pedagogicznej (np. Maciarz, 1993; Zalewska, 2000; Odzimek, 2006; Borowicz, 2009, 2012a; Kobosko, 2011b), a czasem również psychoterapeutycznej. Jak wyraziła to J. Kosmalowa: „W procesie pomagania możemy mówić o profesjonalnej, paraprofesjonalnej i nieprofesjonalnej pomocy psychologicznej. Wszystkie te formy powinny pojawić się jako niezbędny element terapii rodziny dziecka z uszkodzonym narządem słuchu" (2002, s. 33). Rodzicom mogą być również potrzebne różne formy poradnictwa, szkoleń, wsparcia o charakterze mentoringu rodzicielskiego (np. Henderson, 2015; Narr, Kemmery, 2015), wsparcia ze strony specjalnie zorganizowanych dla tego celu grup (np. Kosmalowa, 2002; Kosmalowa, Kobosko, 2002), wsparcia społecznego (np. Kosmalowa, 2002; Borowicz, 2013, 2015; Jamieson, Zaidman-Zait, Poon, 2011). Nie jest łatwo ojcom korzystać z takich form instytucjonalnej pomocy, ale powinni być do tego zachęcani i powinna być ona dla nich łatwo dostępna i oferowana w atrakcyjny 
sposób. Dojrzały psychicznie ojciec będzie mógł być szczęśliwym małżonkiem i ojcem dla wszystkich dzieci w rodzinie.

W dalszych badaniach nad funkcjonowaniem ojców dzieci niesłyszących interesującym byłoby zwrócenie większej uwagi na związki, jakie mogą zachodzić między zmiennymi demograficznymi, osobowościowymi (np. dojrzałość psychiczna, cechy charakteru, system wartości, religijność), generacyjnymi (doświadczeniami z własnego dzieciństwa ojca) oraz związanymi z relacją małżeńską a sprawowaniem przez ojca roli rodzicielskiej i satysfakcji z niej, jego poczucia jakości życia i osobistego szczęścia. Ponadto, jak podkreślają A. Szarkowski i P.J. Brice (2016), w dalszych badaniach należy zwrócić uwagę nie tylko, jak dotychczas, na czynniki stresogenne, wyzwania i trudności rodziców związane z wychowywaniem dziecka niesłyszącego, ale również na ich pozytywne doświadczenia, radości, osiągnięcia, rozwój osobisty.

Dalsze badania nad ojcostwem dzieci niesłyszących powinny również uwzględniać rolę czynników, które wynikają ze zróżnicowania populacji dzieci z uszkodzeniami słuchu. Zupełnie innych problemów doświadczają bowiem ojcowie dzieci z głębokimi uszkodzeniami słuchu, które dzięki protezom funkcjonują jako niedosłyszące lub często nawet jako funkcjonalnie słyszące, a innych ojcowie dzieci, które mimo stosowania protez funkcjonują jako słabosłyszące $\mathrm{z}$ dysfonemią znacznego stopnia. W dotychczasowych badaniach stosowana jest wyłącznie typologia audiometryczna. Warto też zauważyć, że sytuacja dzieci z uszkodzeniami słuchu w ostatnim dwudziestoleciu zmieniła się diametralnie w wyniku przemian w opiece medycznej, technologii protetycznej oraz terapii logopedycznej. Problemy rodziców dzieci z uszkodzeniami słuchu, które badano w XX wieku, i problemy obecne są zupełnie inne. Dlatego wnioski z badań prowadzonych wiele lat temu nie odzwierciedlają obecnej sytuacji rodziców, a tym samym wyzwań, przed jakimi stoją ojcowie dzieci z uszkodzeniem słuchu, i sposobów radzenia sobie z tymi wyzwaniami.

\section{BIBLIOGRAFIA}

Anagnostou, F., Graham, J., Crocker, S. (2007). A preliminary study looking at parental emotions following cochlear implantation. Cochlear Implants International, 8(2), 68-86. DOI: 10.1179/cim.2007.8.2.68

Åsberg, K.K., Vogel, J.J., Bowers, C.A. (2008). Exploring correlates and predictors of stress in parents of children who are deaf: Implications of perceived social support and mode of communication. Journal of Child and Family Studies, 17(4), 486-499. DOI: 10.1007/s10826-0079169-7. 
Barker, D.H., QuitTner, A.L., Fink, N., Eisenberg, L., Tobey, E., Niparko, J., and The CDaCi Investigative Team. (2009). Predicting behavior problems in deaf and hearing children: The influences of language and attention. Development and Psychopathology, 21(2), 373-92. DOI: 10.1017/S0954579409000212.

Blank, A., Frush Holt, R., Pisoni, D.B., Kronenberger, W.G. (2020). Associations between parenting stress, language comprehension, and inhibitory control in children with hearing loss. Journal of Speech, Language, and Hearing Research: JSLHR, 63(1), 321-333. DOI: 10.1044 /2019_JSLHR-19-00230.

Borowicz, A. (2009). O potrzebie tworzenia programów pomocy psychopedagogicznej dla rodziców dzieci z uszkodzeniami słuchu. W: Cz. Kosakowski, A. Krause, M. WóJCIK (red.), Relacje i doświadczenia spoleczne osób z niepetnosprawnościa (s. 241-248). Torun-Olsztyn: Akapit.

Borowicz, A. (2012a). Rehabilitacja dzieci z uszkodzeniami słuchu w kontekście pomocy psychopedagogicznej rodzicom. W: Z. PALAK, D. Chimicz, A. PAWLAK (red.). Wielość obszarów we wspótczesnej pedagogice specjalnej (s. 491-496). Lublin: Wydawnictwo UMCS.

Borowicz, A. (2012b). Stres rodziców wychowujących dzieci z niepełnosprawnością słuchową. Niepetnosprawność - zagadnienia, problemy, rozwiazania, 2(3), 55-80.

Borowicz, A. (2013). Wsparcie społeczne rodziców dzieci z uszkodzeniami słuchu. W: B. SIDOR-PIEKARSKA (red.), Kompetentne wsparcie osób z niepelnosprawnościq (s. 123-146). Lublin: Wydawnictwo KUL.

Borowicz, A. (2015). Wczesna interwencja w zakresie wsparcia dzieci z uszkodzeniami słuchu oraz ich rodzin. W: A. BUjnOwSKA, B. SIDOR-PIEKARSKA (red.), Wczesne wspomaganie rozwoju dziecka $w$ teorii $i$ w praktyce (s. 83-92). Lublin: Wydawnictwo KUL.

Bosteels, S., Van Hove, G., VAndenbroeck, M. (2012). The roller-coaster of experiences: becoming the parent of a deaf child. Disability and Society, 27(7), 983-996. DOI: 10.1080/ 09687599.2012.705059.

Bulicz, K. (2015). Postawy ojców słyszących wobec wspomagania rozwoju ich dziecka z uszkodzonym stuchem. Praca magisterska, KUL, promotor: D. Kornas-Biela.

Burger, T., Löhle, E., Richter, B., Bengel, J., Laszig, R., Spahn, C. (2008). „Ihr Kind ist schwerhörig" - Eine Verlaufsuntersuchung zum elterlichen Befinden [,YYour child is hard of hearing" - a longitudinal study of parental distress]. Laryngorhinootologie, 87(8), 552-559. DOI:10. 1055/s-2007-995577.

CALDERON, R., LOW, S. (1998). Early social-emotional, language, and academic development in children with hearing loss: families with and without fathers. American Annals of the Deaf, 143(3), 225-234. DOI: 10.1353/aad.2012.0115.

Cortelo, F.M., Françozo, M. (2014). Ser pai de filho surdo: da suspeita ao enfrentament [On being a father of a deaf child: from suspicion to coping]. Psicologia em Estudo, Maringá, 19(1), 3-11. DOI: 10.1590/1413-7372189590001.

Crowley, M., Keane, K., Needham, Ch. (1982). Fathers: The forgotten parents. American Annals of the Deaf, 127(1), 38-40. DOI: 10.1353/aad.2012.1334.

CZYŻ, A. (2018). Specyfika badań nad dzieciństwem naznaczonym niepełnosprawnością słuchową. Edukacja Elementarna w Teorii i Praktyce, 13, 4(50), 49-65. DOI: 10.14632/eetp.2018. 13.50.51.

Dirks, E., Uilenburg, N., RiefFe, C. (2016). Parental stress among parents of toddlers with moderate hearing loss. Research in Developmental Disabilities, 55, 27-36. DOI: 10.1016/ j.ridd.2016.03.008. 
DoĞAN, M. (2014). Comparison of the parents of children with and without hearing loss in terms of stress, depression, and trait anxiety. International Journal of Early Childhood Special Education, 2(8653), 232-246. DOI: 10.20489/intjecse.107972.

DomagaŁA-ZyśK, E. (2014). Surdoglottodydaktyka. Lekcje i zajęcia językowe dla uczniów niestyszacych $i$ stabostyszacych. Lublin: Wydawnictwo KUL.

FARNICKA, M. (2011). Wyzwania stojące przed rodziną w sytuacji rozpoznania niepełnosprawności u dziecka. Niepetnosprawność, 6, 18-33.

GAŁKOWSKI, T. (1973). Rehabilitacja dziecka głuchego $w$ wieku przedszkolnym. Warszawa: Akademia Teologii Katolickiej.

GaŁkowski, T., Kunicka-Kaiser, I., SMOLEŃSKA, J., Psychologia dziecka gluchego. Warszawa: PWN.

GóRAlówna, M., DomaŃSKA, A. (1966). Dziecko niestyszace w rodzinie. Warszawa: Państwowy Zakład Wydawnictw Lekarskich.

GóRAlówna, M., HoŁyŃSKA, B. (1984). Rehabilitacja matych dzieci z wadq sluchu. Warszawa: Państwowy Zakład Wydawnictwa Lekarskich.

HADADIAN, A. (1995). Attitudes toward deafness and security of attachment relationships among young deaf children and their parents. Early Education and Development, 6(2), 181-191. DOI: $10.1207 / \mathrm{s} 15566935$ eed0602_6.

HADADIAN, A., Rose, S. (1991). An investigation of parents' attitudes and the communication skills of their deaf children. American Annals of the Deaf, 136(3), 273-277. DOI: 10.1353/aad.2012.0466.

HAGBORG, W.J. (1989). A comparative study of parental stress among mothers and fathers of deaf school-age children. Journal of Community Psychology, 17(3), 220-224. DOI: 10.1002/15206629(198907)17:3<220::AID-JCOP2290170304>3.0.CO;2-N.

HinTERMAIR, M. (2004). Sense of coherence: a relevant resource in the coping process of mothers of deaf and hard-of-hearing children? The Journal of Deaf Studies and Deaf Education, 9(1), 15-26. DOI: 10.1093/deafed/enh005.

Hintermair, M. (2006). Parental resources, parental stress, and socioemotional development of deaf and hard of hearing children. The Journal of Deaf Studies and Deaf Education, 11(4), 493-513. DOI: 10.1093/deafed/en1005.

HinTERMAIR, M., SARIMSKI, K. (2019). Fathers of deaf and hard-of-hearing infants and toddlers experiences, needs, and challenges. The Journal of Deaf Studies and Deaf Education, 24(2), 84-94. DOI: $10.1093 /$ deafed/eny040.

Humphries, T., Kushalnagar, P., Mathur, G., Jo Napoli, D., Rathmann, Ch., Smith, S. (2019). Support for parents of deaf children: Common questions and informed, evidence-based answers. International Journal of Pediatric Otorhinolaryngology, 118, 134-142. DOI: 10.1016/j.ijporl. 2018.12.036.

ILCZUK, G. (1999). Reakcja rodziców na wiadomość o wadzie słuchu dziecka. W: J. KoBosko (red.), Moje dziecko nie styszy (s. 119-122). Warszawa: Stowarzyszenie Przyjaciół Osób Niesłyszących i Niedosłyszących „Człowiek - Człowiekowi”.

INGBER, S., Most, T. (2012). Fathers' involvement in preschool programmes for children with and without hearing loss. American Annals of the Deaf, 157(3), 273-285. DOI: 10.1353/aad. 2012.1620

JAmieson, J., ZAidman-Zait, A., Poon, T. (2011). Family support needs as perceived by parents of preadolescents and adolescents who are deaf or hard of hearing. Deafness and Education International, 13(3), 110-130. DOI: 10.1179/1557069X11Y.0000000005. 
JASIŃSKI, T.J. (2004). Dziecko nie mówi... Badanie przymierza rodzinnego $w$ triadzie matka ojciec-dziecko. Warszawa: Wydawnictwa UW.

JĘDRZEJCZAK, M. (1967). Postawy rodziców mających dzieci głuche. Szkoła Specjalna, 1, 54-62.

KANIOK, P. (2011). Poczucie powodzenia malżeństwa a udzial ojców w opiece nad dzieckiem niepetnosprawnym i w jego wychowaniu. Studia i Monografie $\mathrm{nr}$ 452. Opole: Wydawnictwo UO.

KARWOWSKA, M. (2009). Ojcostwo w samoocenie mężczyzn wychowujących dziecko niepełnosprawne. W: M. BIELSKA-ŁACH (red). Pedagogika specjalna: różne poszukiwania - wspólna misja (s. 359-371). Warszawa: Wydawnictwo Akademii Pedagogiki Specjalnej im. Marii Grzegorzewskiej.

KLACZAK, M. (1996). Rola rodziców dzieci z wadą słuchu w ich wczesnej rehabilitacji. W: R. OsSOWSKI (red.). Trudności w komunikowaniu się osób z uszkodzonym stuchem. Socjalizacja i rehabilitacja (s. 201-211). Bydgoszcz: Wyższa Szkoła Pedagogiczna w Bydgoszczy.

Koвosкo, J. (1999). Stawanie się rodzicem dziecka głuchego to proces. Co możemy zrobić? W: J. Ковоsко (red.), Moje dziecko nie styszy (s. 19-22). Warszawa: Stowarzyszenie Przyjaciół Osób Niesłyszących i Niedosłyszących „Człowiek - Człowiekowi”.

Kовоsко, J. (2009). Relacja matka - dziecko a zaburzenia rozwoju językowego u młodzieży głuchej. Przeglad Psychologiczny, 52(3), 327-342.

Kовоsко, J. (2011a). Parenting a deaf child - how hearing parents cope with the stress of having deaf children. Journal of Hearing Science, 1(3), 39-44.

Kobosko, J. (2011b). Pomoc psychologiczna słyszącym rodzicom a efektywność rehabilitacji dzieci głuchych. Otorynolaryngologia, 10(1), 8-14.

Koвosko, J. (2013a). Depresja matek i ojców a głuchota dziecka. Znaczenie satysfakcji małżeńskiej jako predyktora nasilenia doświadczanych przez rodziców objawów depresji. Roczniki Pedagogiczne, 5(41), 3, 123-140.

Koвosко, J. (2013b). Radzenie sobie ze stresem i samoocena słyszących ojców a głuchota dziecka. Nowa Audiofonologia, 2(1), 36-44.

Kobosko, J., Geremek-Samsonowicz, A., Skarżyński, H. (2014). Problemy zdrowia psychicznego matek i ojców dzieci głuchych z implantem ślimakowym. Otolaryngologia Polska, 68 (3), 135-142.

KoRnAs-BIELA, D. (2001). Rodzice wobec diagnozy uszkodzenia słuchu u dziecka: doświadczenia rodziców, pomoc profesjonalistów. W: D. KornAs-Biela (red.), Rodzina: źródto życia i szkoła miłości (s. 459-477). Lublin: Towarzystwo Naukowe KUL.

KornAs-BielA, D. (2016). Rola ojca we wspomaganiu rozwoju dziecka z uszkodzonym słuchem. W: E. DomagaŁa-ZyśK, A. Borowiec, R. KoŁodziejczyK (red.), Język i wychowanie. Księga jubileuszowa z okazji 45-lecia pracy naukowej Profesor Kazimiery Krakowiak (s. 306-320). Lublin: Wydawnictwo KUL.

Kornas-Biela, D., TuPAJ, K. (2020). Ojcostwo w samoocenie mężczyzn wychowujących dzieci z uszkodzonym słuchem. Część II. Badania empiryczne. Roczniki Pedagogiczne, 12(3), 173-190.

Korzon, A. (2013). Ewolucja stosunku rodziców do dziecka niepełnosprawnego. W: K. ĆWIRYNKAŁo, C. KosakowsKi, A. ŻYwanowsKa, Kierunki rozwoju pedagogiki specjalnej (s. 149156). Kraków: Oficyna Wydawnicza „Impuls”.

Kosmalowa, J. (2001). Program pracy z rodziną dziecka z uszkodzonym narządem słuchu. W: J. KoSMAlOWA (red.). Rehabilitacja dzieci i mlodzieży z uszkodzonym narządem stuchu (s. 51-59). Warszawa: IFPS. 
Kosmalowa, J. (2002). Pomoc rodzinie dziecka z wadą słuchu jako podstawowy element oddziaływań w procesie wczesnej interwencji. Audiofonologia, 21, 129-138.

Kosmalowa, J., Ковоsкo, J. (2002). Grupa wsparcia dla rodziców dzieci z uszkodzonym narządem słuchu. Szkoła Specjalna, 3, 174-180.

Koтоwicz, J. (2020). Naturalna komunikacja pomiędzy dzieckiem głuchym i rodzicem głuchym. W: K. Plutecka, S. Gagat-Matula (red.), Komunikowanie się społeczne osób zagrożonych marginalizacja - konteksty teoretyczne i praktyczne rozwiazania. Kraków: Wydawnictwo Naukowe Uniwersytetu Pedagogicznego. DOI: 10.24917/9788380844094.6.

KRAKOWIAK, K. (2001). O potrzebie pomocy dla rodzin wychowujących dzieci z uszkodzeniami słuchu. W: D. Kornas-Biela (red.), Rodzina: źródło życia i szkoła miłości (s. 339-358). Lublin: Towarzystwo Naukowe KUL.

Krakowiak, K. (2013). Dar języka. Podręcznik metodyki wychowania językowego dzieci i młodzieży z uszkodzeniami narządu stuchu. Lublin: Wydawnictwo KUL.

Kurtzer-White, E., Luterman, D. (2003). Families and children with hearing loss: Grief and coping. Mental Retardation and Developmental Disabilities. Research Reviews, 9(4), 232-235. DOI: $10.1002 / \mathrm{mrdd} .10085$

Lederberg, A.R., Golbach, T. (2002). Parenting stress and social support in hearing mothers of deaf and hearing children: A longitudinal study. Journal of Deaf Studies and Deaf Education, 7(4), 330-345. DOI: 10.1093/deafed/7.4.330.

MACIARZ, A. (1993). Wspomaganie rodziny w wypełnianiu podmiotowej roli w wychowaniu i rehabilitacji dzieci. W: R. Kostecki, A. MACIARZ (red.), Podmiotowa rola rodziców w rehabilitacji dzieci niepetnosprawnych. Zielona Góra: Wyższa Szkoła Pedagogiczna im. T. Kotarbińskiego.

MarcinKowsKa, J. (2009). Rodzice wobec głuchoty dziecka. W: M. KowalsKa (red.), Moje głuche dziecko. Kompendium wiedzy na temat rehabilitacji dziecka głuchego (s. 7-17). Łódź: Polski Związek Głuchych/Oddział Łódzki.

Mavrogianni, T., LAmpropoulou, V. (2020). The involvement of fathers with their deaf children. International Journal of Disability, Development and Education, 67(1), 45-57. DOI: 10.1080/ $1034912 X .2018 .1551520$.

Meadow-Orlans, K.P. (1995). Sources of stress for mothers and fathers of deaf and hard of hearing infants. American Annals of the Deaf, 140(4), 352-357. DOI: 10.1353/aad.2012.0392.

Meadow-Orlans, K.P. (1994). Stress, support, and deafness: Perceptions of infants' mothers and fathers. Journal of Early Intervention, 18(1), 91-102. DOI: 10.1177/10538151940180010 8.

Meadow-Orlans, K.P. (1990). The Impact of Childhood Hearing Loss on the Family. W: D.F. Moores, K.P. Meadow-Orlans (red.), Educational and Developmental Aspects of Deafness (s. 321-338). Gallaudet University Press.

Meadow-Orlans, K.P., Dyssegaard, B., Smith-Gray, S. (2004). Hearing Parents' Reactions to the Identification of Deafness and Cognitive or Motor Disabilities. W: K.P. MEADOW-ORLANS, P.E. Spencer, L.S. Koester (red.), The World of Deaf Infants. A Longitudinal Study. Oxford Scholarship Online. DOI:10.1093/acprof:oso/9780195147902.003.0006.

Meadow-Orlans, K.P., Mertens, D.M., Sass-Lehrer, M.A., Scott-Olson, K. (1997). Support services for parents and their children who are deaf or hard of hearing. A national survey. American Annals of the Deaf, 142(4), 278-288. DOI:10.1353/aad.2012.0221.

Meadow-Orlans, K.P., Mertens, D.M., Sass-Lehrer, S.A. (2003). Parents and Their Deaf Children: The Early Years. Washington DC: Gallaudet University Press. 
NARR, R.F., KEMMERY, M. (2015). The nature of parent support provided by parent mentors for families with deaf/hard-of-hearing children: Voices from the start. The Journal of Deaf Studies and Deaf Education, 20(1), 67-74. DOI: 10.1093/deafed/enu029.

Nicholas, J.G., Geers, A.E. (2003). Personal, social, and family adjustment in school-aged children with a cochlear implant. Ear Hearing, 24(1Suppl), 69S-81S. DOI: 10.1097/01.AUD. 0000051750.31186.7A.

Noohi, S., Ghalamfarsa, M., Davoudi Monfared, E. (2018). Comparing anxiety, depression, and stress in consanguineous versus non-consanguineous parents of children with deafness in Baqiyatallah Hospital's Cochlear Implant Center From 2007 to 2009. Hospital Practices and Research, 3(3), 85-89. DOI: 10.15171/hpr.2018.19.

ODZIMEK, B. (2006). Pomoc psychologiczna rodzinom dzieci z uszkodzeniami słuchu. W: K. KRAKOWIaK, A. DzIURda-Multan (red.), ,, Nie glos, ale stowo... ”. Przekraczanie barier w wychowaniu osób z uszkodzeniami stuchu (s. 303-314). Lublin: Wydawnictwo KUL.

Pipp-Siegel, S., Sedey, A.L., Yoshinaga-Itano, C. (2002). Predictors of parental stress in mothers of young children with hearing loss. Journal of Deaf Studies and Deaf Education, 7(1), 1-17. DOI: $10.1093 /$ deafed/7.1.1.

PluteCKA, K. (2013a). Ojciec wobec osiagnięć edukacyjnych dziecka niestyszacego. Prace Monograficzne nr 648. Kraków: Wydawnictwo Naukowe Uniwersytetu Pedagogicznego.

PluteCKA, K. (2013b). Rola ojca w rehabilitacji dziecka niesłyszącego z implantem ślimakowym. W: K. ĆWIRYNKalo, Cz. Kosakowski, A. ŻYwanowska (red.), Kierunki rozwoju pedagogiki specjalnej (s. 265-276). Kraków: Oficyna Wydawnicza „Impuls”.

PlutecKa, K. (2017). Stres i radzenie sobie z nim przez rodziców dzieci niesłyszących, Społeczeństwo i Rodzina, 50(1), 58-69.

Punch, R., Hyde, M.B. (2011). Communication, psychosocial, and educational outcomes of children with cochlear implants and challenges remaining for professionals and parents. International Journal of Otolaryngology. Article ID 573280. DOI: 10.1155/2011/573280.

Quittner, A.L., Barker, D.H., Cruz, I., Snell, C., Grimley, M.E., Botteri, M., The CDaCI Investigative Team (2010). Parenting stress among parents of deaf and hearing children: Associations with language delays and behavior problems. Parenting: Science and Practice, 10(2), 136-155. DOI: 10.1080/15295190903212851.

Skalbania, B., MarszaŁeK, E. (2010). Postawy ojców wobec ich niepełnosprawnych dzieci w świetle badań własnych. W: Z. PALAK, A. BujnowsKa, A. PAWLAK (red.), Aktualne problemy edukacji i rehabilitacji osób niepetnosprawnych w biegu życia (s. 142-153). Lublin: Wydawnictwo UMCS.

Spahn, C., Burger, T., Löschman, Ch., Richter, B. (2004). Quality of life and psychological distress in parents of children with a cochlear implant. Cochlear Implants International, 5(1), 13-27. DOI: 10.1080/14670100.2004.11873747.

SzARKowsKi, A., BRICE, P.J. (2016). Hearing parents' appraisals of parenting a deaf or hard-ofhearing child: application of a positive psychology framework. The Journal of Deaf Studies and Deaf Education, 21(3), 249-258. DOI: 10.1093/deafed/enw007.

TręBicka-Postrzygacz, B. (1999). Dziecko niesłyszące w rodzinie. Audiofonologia, 14, 93-101.

Vukkadala, N., Giridhar, S.B.P., OKumura, M.J., Chan, D.K. (2019). Seeking equilibrium: The experiences of parents of infants and toddlers who are deaf/hard-of-hearing. Journal of Pediatric Rehabilitation Medicine, 12(1), 11-20. DOI: 10.3233/PRM-170528. 
Yuelin, L., Bain, L., Steinberg, A.G. (2003). Parental decision making and the choice of communication modality for the child who is deaf. Archives of Pediatric and Adolescent Medicine, 157(2):162-168. DOI: 10.1001/archpedi.157.2.162.

Yoshinaga-ITAno, C. (2003). From screening to early identification and intervention: discovering predictors to successful outcomes for children with significant hearing loss. Journal of Deaf Studies and Deaf Education, 8(1), 11-30. DOI:10.1093/deafed/8.1.11.

ZACZYŃSKA, M. (2001). Być ojcem dziecka głuchego. W: J. KoBosKo (red.), Bliżej życia. Materiaty dla rodziców dzieci i młodzieży z wada słuchu. Warszawa: Stowarzyszenie Przyjaciół Osób Niesłyszących i Niedosłyszących „Człowiek - Człowiekowi”.

ZAIDMAn-ZAit, A. (2007). Parenting a child with a cochlear implant: A critical incident study. Journal of Deaf Studies and Deaf Education, 12(2), 221-241. DOI: 10.1093/deafed/enl032.

ZAIDMAN-ZAIT, A. (2008). Everyday problems and stress faced by parents of children with cochlear implants. Rehabilitation Psychology, 53(2), 139-152. DOI: 10.1037/0090-5550.53. 2.139.

Zaidman-Zait, A., Most, T., TARrasch, R. Haddad, E. (2018). Mothers' and fathers' involvement in intervention programs for deaf and hard of hearing children. Disability and Rehabilitation, 40(11),1301-1309. DOI: 10.1080/09638288.2017.1297491.

Zaidman-Zait, A., Most, T., Tarrasch, R., Haddad-eid, E., Brand D. (2016). The impact of childhood hearing loss on the family: Mothers' and fathers' stress and coping resources. Journal of Deaf Studies and Deaf Education, 21(1), 23-33. DOI: 10.1093/deafed/env038.

ZAKRZEWSKA-MANTERYS, E., (2011). Lista obecności: rozmowy z ojcami osób z zespolem Downa. Warszawa: Stowarzyszenie Rodzin i Opiekunów Osób z Zespołem Downa Bardziej Kochani.

ZalewsKa, M. (2000). Pomoc psychologiczna słyszącym rodzicom dziecka głuchego. W: H. SIEDLECKA, E. KULCZYCKA (red.). Wspótczesne kierunki wczesnej diagnozy i wczesnej rewalidacji dziecka $z$ wada stuchu (s. 33-36). Warszawa: Wydawnictwo APS.

\section{Netografia}

Henderson, R. (2015). Parent-to-Parent Support for Parents of Children who are Deaf or Hard of Hearing: A Conceptual Framework. Electronic Thesis and Dissertation Repository. 3116. https://ir.lib.uwo.ca/etd/3116R. (dostęp: 16.05.2020).

KorneluK, R. LubAŃSKi, M. BRodowsKa-PotrZeBowska, K. KochANEK (2012) Krótka nota o Instytucie Fizjologii i Patologii Słuchu w świetle prezentowanego programu. https://whc.ifps. org.pl/wp-content/uploads/2012/03/materialy-prasowe_ost_1-2.pdf. (dostęp: 14.05.2020).

Szarkowski, A., Dirks, E. (2019-2020). Parental Self-Efficacy and Parental Involvement in Fathers and Mothers of Children with Hearing Loss. https:/www.nsdsk.nl/file/download /default/8C19892541C0A6769EAFC7B8CD1F8FFF/Fathers\%20are\%20important\%20partne rs.pdf (dostęp: 15.05.2020). 


\section{OJCOSTWO MĘŻCZYZN WYCHOWUJĄCYCH DZIECI Z USZKODZONYM SŁUCHEM CZĘŚĆ I}

\section{STRESZCZENIE}

Uszkodzenie słuchu u dziecka jest wyzwaniem dla jego rodziców. Dzięki wczesnej diagnozie rodzice mogą podjąć decyzję o leczeniu i wspomaganiu rozwoju dziecka niesłyszącego od okresu niemowlęctwa. Literatura surdopedagogiczna jest skupiona szczególnie na roli matki w rozwoju takiego dziecka, jej doświadczeniach i przeżyciach oraz skutkach głuchoty w jej funkcjonowaniu. Niniejszy artykuł poświęcony jest przeglądowi literatury polskiej i zagranicznej na temat ojcostwa wobec dziecka niesłyszącego i ma na celu ukazać obszary zainteresowania badaczy ojcostwem dziecka $\mathrm{z}$ niepełnosprawnością słuchową, takie jak np. znaczenie obecności ojca $\mathrm{w}$ życiu dziecka niesłyszącego, rola ojca, jego zaangażowanie w opiekę, stres ojcowski/rodzicielski i jego skutki dla dziecka, rodziców i całej rodziny, poczucie skuteczności i koherencji u ojców, radzenie sobie z problemami, wsparcie społeczne, zaburzenia zdrowia psychicznego u ojców. W zakończeniu podkreślono konieczność wsparcia dla ojców/rodziców dzieci z uszkodzeniem słuchu oraz wysunięto postulaty co do dalszych badań dotyczących ojcostwa dzieci niesłyszących.

Słowa kluczowe: ojcostwo; głuchota; ojciec dziecka niesłyszącego; rodzice dzieci z uszkodzeniem słuchu; niepełnosprawność w rodzinie.

\section{FATHERHOOD IN MEN RAISING CHILDREN WITH A HEARING-IMPAIRMENT \\ PART I}

\section{SUMMARY}

A child's hearing impairment is a challenge for parents. Thanks to early diagnosis, parents can decide to treat and support the development of a deaf child already from infancy. The surdopedagogical literature mainly focuses on the role of the mother in the development of such a child, her experiences, as well as the effects of deafness on her functioning. The present article offers a review of Polish and foreign literature on fatherhood with a deaf child and aims to show the researchers' interest areas in paternity in relation to a child with hearing impairment, including: the importance of the father's presence in the life of a deaf child, the role of the father, his commitment to care, paternal/parental stress and its effects on the whole family, a sense of efficiency and coherence in fathers, coping with problems, social support, mental health disorders in fathers. Finally, the paper proposes postulates for further research on the fatherhood of deaf children.

Key words: fatherhood; deafness; hearing impairment; father of a deaf child; parents of children with hearing impairment; disability in family. 